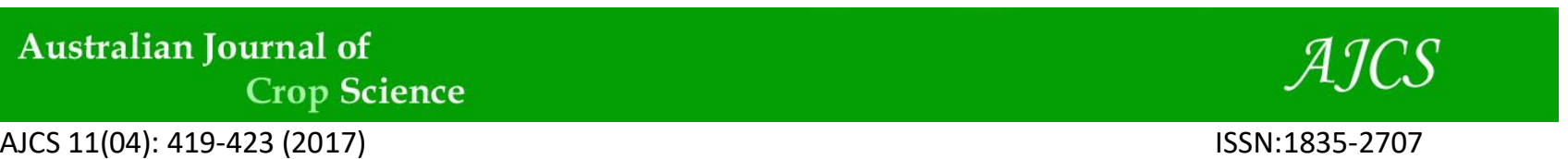

AJCS 11(04): 419-423 (2017)

ISSN:1835-2707

doi: 10.21475/ajcs.17.11.04.pne299

\title{
Postharvest responses of tannia (Xanthosoma sagittifolium) leaves to mechanical wounding
}

\author{
Teresa D. C. Mendes ${ }^{1}$, Christiane de F. M. França ${ }^{2}$, Kharen P. O. S. Petrucci ${ }^{2}$, Cristina S. Souza ${ }^{3}$, \\ Joice S. Santos ${ }^{4}$, Fernando L. Finger ${ }^{2 *}$ \\ ${ }^{1}$ Federal Institute of Southeast of Minas Gerais, 36205-018 - Barbacena - MG, Brazil \\ ${ }^{2}$ Federal University of Viçosa, Department of Plant Science, 36570-000, Viçosa, MG, Brazil \\ ${ }^{3}$ Federal University of Uberlândia, Plant Science Institute, 38400-902, Uberlândia, MG, Brazil \\ ${ }^{4}$ Federal Institute of Education, Science and Technology of Sertão Pernambucano, 56300-000, Petrolina, PE, \\ Brazil
}

\section{*Corresponding author: ffinger@ufv.br}

\begin{abstract}
Tannia leaves are consumed in many regions of Tropical Americas and Africa. Due to large size and fragility, leaves are subjected to physical wounding during handling. As a result, visual symptoms of yellowing develop at wounding and adjacent tissues. The aim of this study was to evaluate the effect of mechanical injury on the physiological changes of tannia leaves at damaged tissue and adjacent areas. For this purpose, the lamina of leaves was perforated for several times with a needle. Then, the leaf samples were excised off as follows: a $0.6 \mathrm{~cm}$ diameter (circle A), containing the injured area; $1.1 \mathrm{~cm}$ O-ring B, around the circle A, $1.6 \mathrm{~cm}$ O-ring $\mathrm{C}$, around the B. Control samples were taken from the opposite side of the leaves free of any wounding. Analysis of fresh weight loss and concentration of soluble phenolic compounds were performed after $30 \mathrm{~min}, 2,4$ and $6 \mathrm{~h}$ and the leaf chlorophyll content was determined after $30 \mathrm{~min}, 24,48$ and $72 \mathrm{~h}$. The mechanical injury increased the postharvest accumulated fresh weight loss by $59.1 \%$ on circle A and by $22.6 \%$ on O-ring B after $6 \mathrm{~h}$. The injured circle A accumulated $56 \%$ more soluble phenolic over the period of $6 \mathrm{~h}$, which can be related to the activation of defense mechanism by the cell. The rate of chlorophyll degradation was not affected by the injury up to $72 \mathrm{~h}$ after wounding. Leaf wounding increases fresh weight loss and induces accumulation of soluble phenolic compounds at location of the injury.
\end{abstract}

Received 13 Aug 2016; Revised 19 Nov 2016; Accepted 17 Feb 2-17.

Keywords: Chlorophyll; Fresh matter; Phenolic compounds; Leaf vegetable.

\section{Introduction}

Tannia (Xanthosoma sagittifolium (L.) Schott) is a leafy vegetable that requires high temperatures for proper growth (Seganfredo et al., 2001). Therefore, its production and consumption is restricted to tropical and subtropical regions of Americas and Africa. Nevertheless, production and consumption of these ethnical vegetables in the United States of America is increasing due to the large community of Brazilians and Africans in Northeastern states and Florida (Mangan et al., 2008). Several vegetables are appreciated by the Brazilian population living in the USA, but fruits of maxixe (Cucumis sativus) and gilo (Solanum gilo), and tannia leaves are the most popular cooking vegetables.

Improper postharvest handling of vegetables results in mechanical injury especially in large and delicate leaves like tannia, which induces changes on the general metabolism, altering color, texture and nutritional value of the product (Cantwell and Suslow, 2002). Darkening of lettuce induced by mechanical injury is the result of synthesis and accumulation of phenolic compounds in distant cells up to 2 $\mathrm{cm}$ from the site of injury (Campos-Vargas and Saltveit, 2002). Another change that follows the injury is the yellowing due to chlorophyll degradation, which according to Mao et al. (2007) is the main reason for intense loss of green color in fresh cut kiwi fruits.

Mechanical injury also causes changes in the texture, turning the leaves wilted and with lower fresh weight due to more intense water loss. Thompson (2005) found that heavier wounding causes petiole cracking and shatter bruise and accelerated water loss in pact choi leaves. This fact occurs because at the damage site the integrity of membranes is lost, allowing leakage of solutes present inside the cell and loss of cell turgor (Toivonen and Brummell, 2008). In addition, mechanical wounds may cause metabolic changes of phenol compounds by increasing the activity of key enzymes from the phenylpropanoid synthesis as determined in carrots (Stodolak et al., 2003). These responses may occur after a few minutes to some hours after the injury at the damage site (local response) and at undamaged adjacent tissues (systemic response) (Leon et al., 2001). In tannia leaves, mechanical injury is visually detected by the yellowing, and later, some darkening restricted to the damaged region, not extending to the entire leaf (Mendes et al., 2011). The aim of this study was to evaluate the effect of mechanical injury on the physiological changes of tannia leaves and the eventual systemic responses from the site of injury into the adjacent undamaged areas.

\section{Results and Discussion}

There was significant increase in loss of fresh weight in response to mechanical injury in circle A and O-ring B (Figs 1 and 2). The circle A and O-ring B showed accumulated 


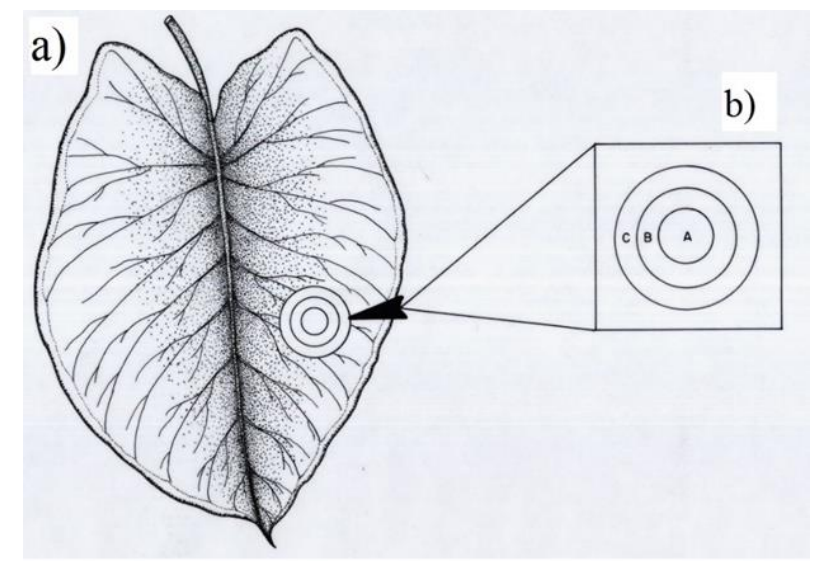

Fig 1. Drawing of tannia leaf showing the needle perforated site circle $A(a, b)$. Leaf punchers used to remove the circle $A$ and $O$ rings $\mathrm{B}$ and $\mathrm{C}$ from the leaf (b). Diameters of $0.6 \mathrm{~cm}$ (circle A), $1.1 \mathrm{~cm}(\mathrm{O}$-ring B) and $1.6 \mathrm{~cm}(\mathrm{O}$-ring C).

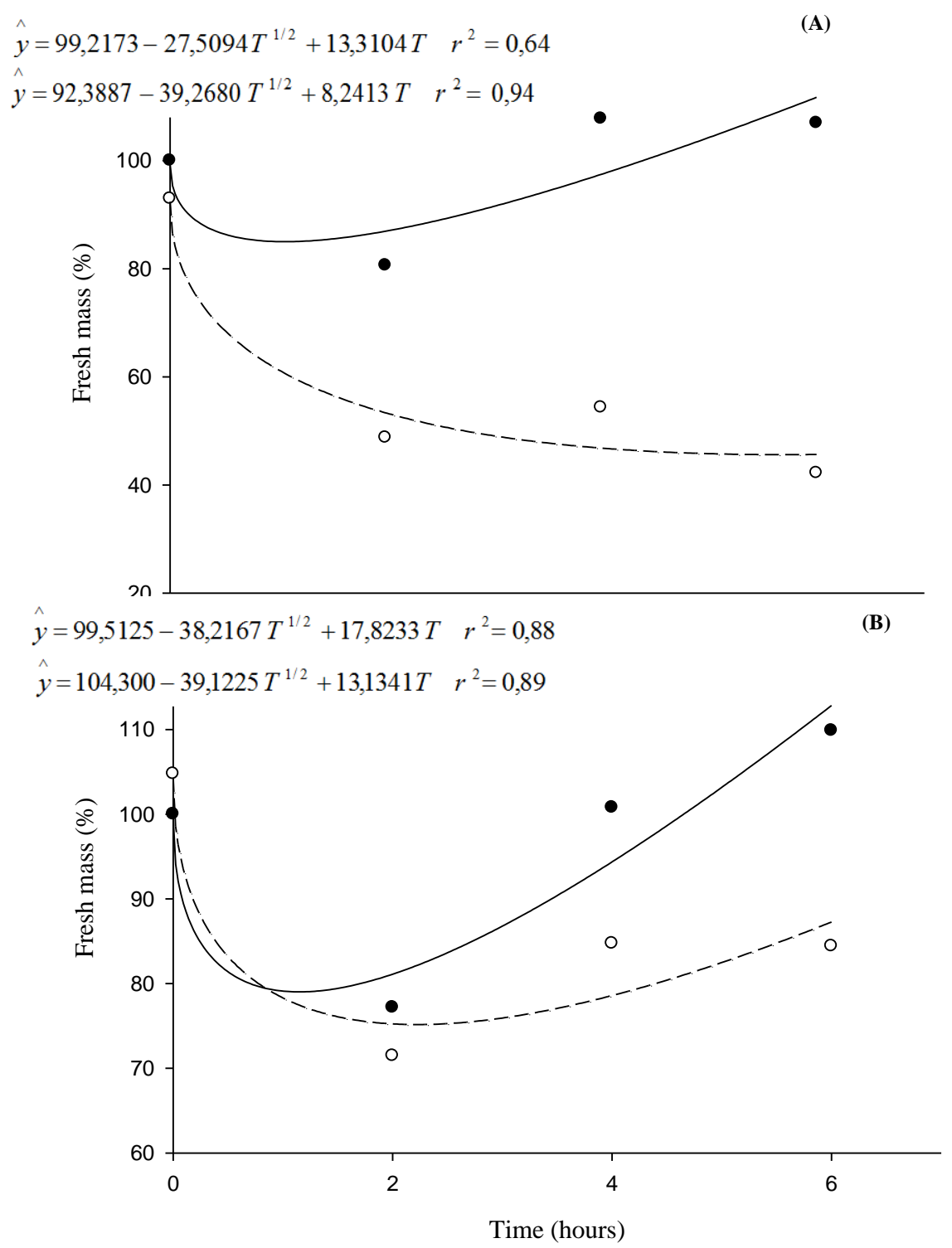

Fig 2. Variation of fresh weight in circle A (A) and O-ring B (B) control ) and injured (------) over time after the physical wounding stored at $22{ }^{\circ} \mathrm{C}$. 


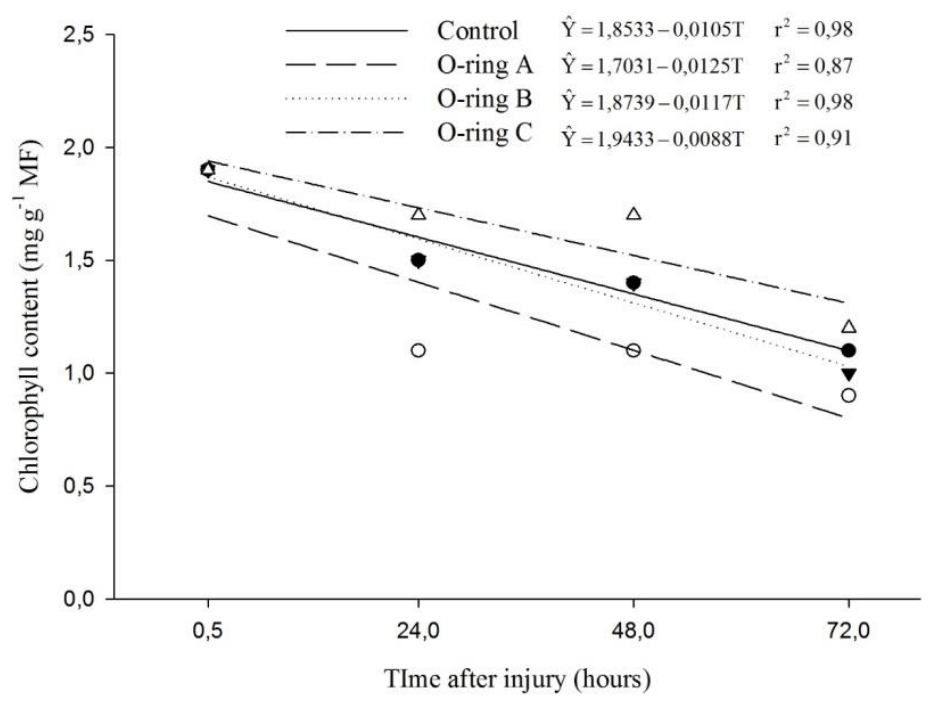

Fig 3. Changes in chlorophyll content in wounded circle A, O-rings B and C, and control leaves stored at $22^{\circ} \mathrm{C}$.

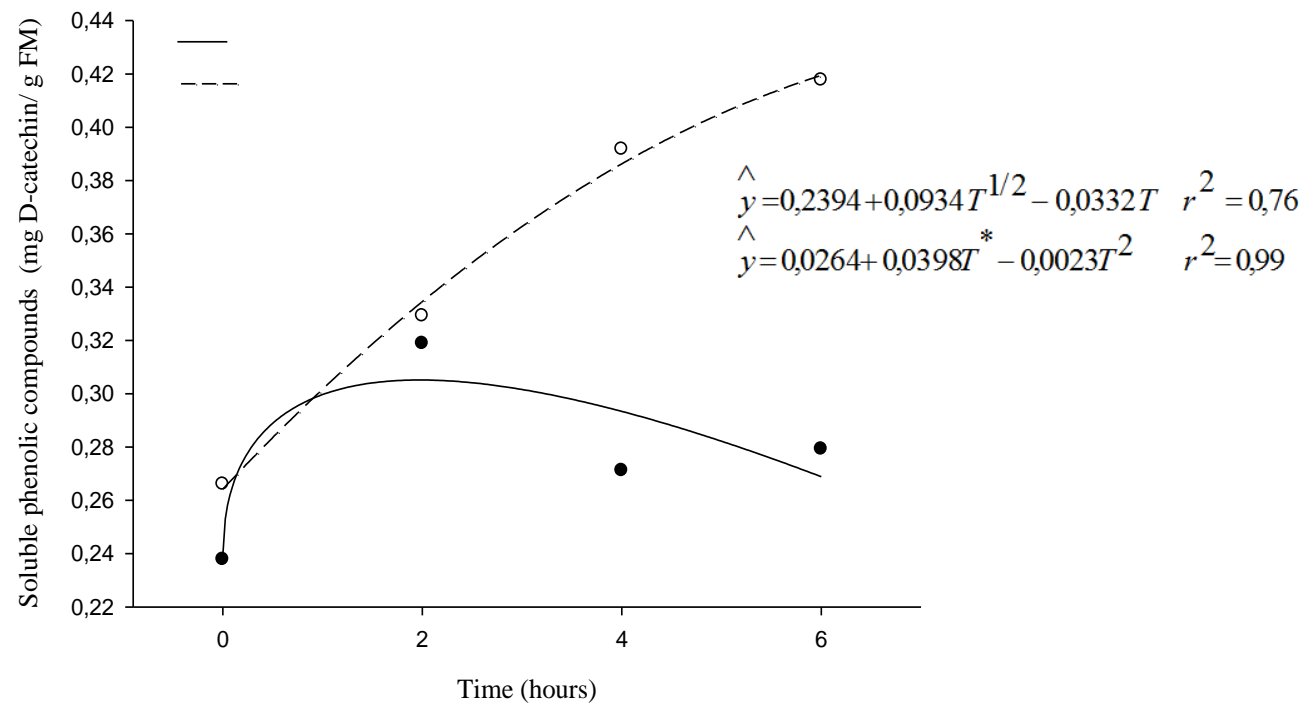

Fig 4. Variation on phenolic compounds in circle A control (— ) and needle wounded (----) over time after the physical injury stored at $20^{\circ} \mathrm{C}$.

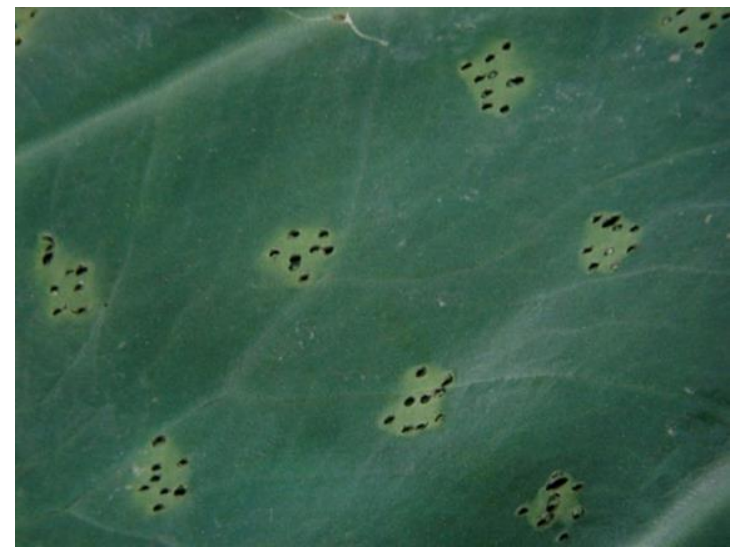

Fig 5. Symptoms of color change in leaves of tannia after 24 hours of needle physical injury stored at $20{ }^{\circ} \mathrm{C}$. 
reductions of 59.1 and $22.6 \%$ of fresh weight, compared to the control, after 6 hours of the injury (Fig 1), while on the Oring $\mathrm{C}$ the fresh weight variation was similar to control (data not shown). Wounding is considered in fresh cut products, because of the intense water loss and induction of enzymes from the phenylpropanoid pathway (Hodges and Toivonen, 2008). There was an increase in the percentage of fresh weight in the first 6 hours of shelf life for the control leaves, O-rings B and C (Figs 1 and 2). This increase occurred due to the uptake of water by the leaves, since the base of the petiole submerged and remained in water during whole period of evaluation. But the circle A did not showed increase in the fresh weight. The mechanical injury caused higher decrease in fresh weight in the wounded region, as well as in the closest adjacent tissue. According to Ke and Saltveit (1989) the signal of mechanical injury starts at the site of injury and moves into the adjacent tissues at about $0.5 \mathrm{~cm} / \mathrm{h}$. This phenomenon also appears to occur at postharvest stage of wounded leaves of tannia stored at room temperature. According to Mahajan et al. (2008) when the product loses 5 to $10 \%$ of the initial fresh weight it becomes wilt and unusable. Thus, in injured tannia leaves there is a decreased in fresh weight about $39 \%$ in the first 2 hours from the occurrence of mechanical injury, making them unusable for marketing.

Regardless of treatment, over a period of 72 hours, chlorophyll degradation occurred at similar rates on control, injured circle A and adjacent O-rings B and C (Fig 3). Postharvest chlorophyll degradation, at experimental conditions of this work, was much more related to the leaf senescence process than the mechanical injury applied.

The content of phenolic compounds in the injured circle A accumulated by $56 \%$ after six hours, compared to uninjured control leaves (Fig. 4). For the injured O-rings B and C, there was no accumulation phenolic compounds compared to the control. Thus, the elevation of soluble phenolic compounds seems to be a limited response to the local of injury and may be responsible for the discoloration observed at wounding site (Fig 5). Similarly, this behavior occurred in carrots with different injury intensities but with higher accumulation of phenolics in the regions with greater intensity of damage (Heredia and Cisneros-Zevallos, 2009). In lettuce, the accumulation of soluble phenolic compounds, induced by wounding, included de novo synthesis of phenylalanine ammonia lyase and subsequent tissues browning (Choi et al., 2005). In general, browning reaction is linked to direct action of polyphenol oxidase on phenolic compounds (Toivonen and Brummell, 2008). The storage of leaves of the same clone at $10{ }^{\circ} \mathrm{C}$ for 20 days had significant increase in content of phenolic compounds and concomitant stimulation of catalase activity, but no visual symptom of chilling injury was developed (Souza et al., 2014). Witkowska and Woltering (2013) found that the response of two lettuce cultivars to wound-induced senescence was affected by the age of the plant, in which the senescence was delayed in younger leaves. Thus, further studies on leaf harvest of tannia 'Comum', at different ages can determine the role of enzymes associated with cellular defense mechanisms, since this work showed increase in phenolic compounds due to wounding without induction of chlorophyll degradation.

\section{Materials and Methods}

\section{Plant material}

Fully expanded leaves of tannia clone BGH 'Comum' (edible) were harvested in the morning from a garden field at Federal
University of Viçosa $\left(20^{\circ} 45^{\prime} \mathrm{S}\right.$ and $651 \mathrm{~m}$ a.s.1.) and kept with the base of the petiole inside a vase with distilled water at stored at $22{ }^{\circ} \mathrm{C}$ under $10 \mu \mathrm{mol} \mathrm{m}{ }^{-2} \mathrm{~s}^{-1}$ constant fluorescent light up to the end of the shelf life.

\section{Treatments}

The leaf of individual plants was perforated with 6 to 8 holes using a needle of $0.8 \mathrm{~mm}$ in diameter, covering an area of $1.15 \mathrm{~cm}^{2}$ simulating mechanical injuries. To verify if there was extended changes resulting from injury to adjacent tissues, O-rings were taken from the site of the needle inflicted injury, comprising the $0.6 \mathrm{~cm}$ diameter (circle A),

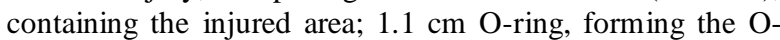
ring $\mathrm{B}$, around the circle $\mathrm{A}$, and $1.6 \mathrm{~cm} \mathrm{O-ring}$, forming the O-ring C, around the B (Fig. 1a,b). Uninjured controls circles and O-rings were taken from the unwounded opposite side of the leaf.

\section{Traits measured}

Fresh weight loss and concentration of soluble phenolics compounds were performed after 30 minutes, 2, 4 and 6 hours after the mechanical injury stored at $22{ }^{\circ} \mathrm{C}$ under constant white fluorescent light at $10 \mu \mathrm{mol} \mathrm{m} \mathrm{m}^{-2} \mathrm{~s}^{-1}$. The concentration of soluble phenolic compounds was determined following the procedure described by Prince and Butler (1977) using D-catechin as standard. Quantification of chlorophyll content was made according to Arnon (1949), after 30 minutes, 24, 48 and 72 hours of wounding.

\section{Data analysis}

The statistical design was set up in three randomized block with containing a total of twelve individual leaves. Each block was composed by four replicates of A circles or B and $\mathrm{C}$ O-rings removed individual leaves. Data were subjected to analysis of variance (ANOVA) and regression analysis at $P<0.05$.

\section{Conclusion}

Postharvest physical injury in leaves of tannia causes severe reduction in the fresh weight and increases the accumulation of soluble phenolic compounds mainly in the location of the injury. Mechanical injury has no effect on the chlorophyll degradation of these leaves up to $72 \mathrm{~h}$ after wounding.

\section{Acknowledgements}

Thanks to FAPEMIG, CNPQ and CAPES for financial assistance.

\section{References}

Arnon DI (1949) Copper enzymes in isolated chloroplasts: Polyphenoloxidase in Beta vulgaris. Plant Physiol. 24:1-15.

Campos-Vargas R, Saltveit ME (2002) Involvement of putative chemical wound signals in the induction of phenolic metabolism in wounded lettuce. Physiol Plant. 114:73-84.

Cantwell MI, Suslow TV (2002) Postharvest handling systems: fresh-cut fruits and vegetables. In: Kader AA (ed) Postharvest Technology of Horticultural Crops, 3rd edn. California, University of California.

Choi Y-J, Tomas-Barberán FA, Saltveit ME (2005) Woundinduced phenolic accumulation and browning in lettuce 
(Lactuca sativa L.) leaf tissue is reduced by exposure to nalcohols. Postharvest Biol Tec. 37: 47-55.

Heredia JB, Cisneros-Zevallos L (2009) The effect of exogenous ethylene and methyl jasmonate on pal activity, phenolic profiles and antioxidant capacity of carrots (Daucus carota) under different wounding intensities. Postharvest Biol Tec. 51:-242-249.

Hodges DM, Toivonen PMA (2008) Quality of fresh-cut fruits and vegetables as affected by exposure to abiotic stress. Postharvest Biol Tec. 48: 155-162.

Ke D, Saltveit ME (1989) Wound- induced ethylene production phenolic metabolism susceptibility to russet spotting in Iceberg lettuce. Physiol Plant. 76: 412-418.

León J, Rojo E, Sánchez-Serrano JJ (2001) Wound signaling in plants. J Exp Bot. 52: 1-9.

Mangan FX, Mendonça RU, Moreira M, Nunes SV, Finger FL, Barros ZJ, Galvão H, Almeida GC, Silva RAN, Anderson MD (2008) Production and marketing of vegetables for the ethnic markets in the United States. Hort Bras. 26: 6-14.

Mahajan PV, Oliveira FAR, Macedo, I (2008) Effect of temperature and humidity on the transpiration rate of the whole mushrooms. J Food Eng. 84: 281-288.

Mao L, Wang G, Que F (2007) Application of 1methylcyclopropene prior to cutting reduces wound responses and maintains quality in cut kiwi fruit. J Food Eng. 78: 361-365.
Mendes TDC, Santos JS, Vieira LM, Cardoso, DSCP, Finger FL (2011) Influência do dano físico na fisiologia póscolheita de folhas de taioba. Bragantia 70: 682-687.

Prince ML, Butler LG (1977) Rapid visual estimation and spectrophotometric determination of tannin content of sorghum grain. J Agric Food Chem. 25:1268-1273.

Seganfredo R, Finger FL, Barros RS, Mosquim PR (2001) Influência do momento de colheita sobre a deterioração pós-colheita em folhas de taioba. Hort Bras. 19:184-187.

Souza CS, Finger FL, Casali VWD, Cecon PR (2014) Effect of cold storage on enzyme activity and postharvest conservation of tannia (Xanthosoma sagittifolium) leaves. Aust J Crop Sci. (8) 10:1380-1387.

Stodolak B, Leja M, Mareczek A (2003) Some aspects of metabolism of phenolics in carrot root slices. Food Agric Environ. 1: 88-94.

Toivonen PMA, Brummell DA (2008) Biochemical bases of appearance and texture changes in fresh-cut fruit and vegetables. Postharvest Biol Tec. 48:1-14.

Thompson GE (2005) Role of harvest technique and injuries in water loss from stored pak choi (Brassica rapa subsp. chinensis) heads. New Zeal J Crop Hort Sci. 33: 111-115.

Witkowska IM, Woltering EJ (2013) Plant age affects wound-induced senescence in Lactuca sativa L. Plant Biochem Physiol. 2: 1-11. 